\title{
Computer Simulation of Laser Welding Technology of Chrome-Nickel Steels in Automotive Industry and its Verification by Means of Electron Microscopy
}

\author{
Petra Kvasnová ${ }^{1}$, Daniel Novák ${ }^{1}$, Viktor Novák ${ }^{2}$, Ján Stebila ${ }^{1}$ \\ ${ }^{1}$ Matej Bel University, Faculty of Natural Sciences, Department of Technology, Tajovského 40, 97401 Banská Bystrica, \\ Slovakia.E-mail: petra.kvasnova@umb.sk, daniel.novak@umb.sk,jan.stebila@umb.sk \\ ${ }^{2}$ Czech University of Life Sciences Prague, Faculty of Engineering, Department of Electrical Engineering and Automa- \\ tion, Kamýcká 129, 16521 Prague 6, Czech Republic. E-mail: novakviktor@tf.czu.cz
}

\begin{abstract}
Numerical simulation of technological processes enables their exact description and it makes possible to get closer to the real process courses. The described method uses mathematical models transformed into the finite element method. The processes of interaction of the laser beam with the surface of austenitic stainless steel are first observed on simple geometrical models. Hereby the basic parameters of the processes are analyzed, and individual welding stages are described as dynamic fluid systems, in which steel is in a liquid state and it behaves as an incompressible fluid, while it is simultaneously loaded by the heat flux from the laser beam. Subsequently, threedimensional models are analyzed using thermal and structural elements. Due to the high density of heat flow in the material, an orthotropical material model with equivalent coefficients of thermal conductivity of steel has to be used. The results obtained by numerical analyzes represent a sufficient picture of the behavior of the material when exposed to the laser beam, and they show the distribution of temperature, velocity and stress fields during welding. The acquired knowledge can be suitably used both in the automotive industry and also in many other industry branches.
\end{abstract}

Keywords: Computer simulation, Welding, Bodywork, Austenitic stainless steel, Electron microscopy

\section{References}

[1] ARSLAN, S., TURSUN, N., KURTULMUS, F., GÜLEC, D. (2016). Use of thermal images for optimizing burner height, operating pressure, and burner angle of a weed flamer. In: Agronomy Research, Vol. 14, No. 1, pp. 14-24. Estonian University of Life Sciences, Tartu, Estonia. ISSN 1406-894X.

[2] Tillová, E., CHAlupová, M., HuRtalová, L., ĎURiNíKOVÁ, E. (2011). Quality control of microstructure in recycled Al-Si cast alloys. In: Manufacturing Technology, Vol. 11, pp. 70-76. J. E. Purkyne University in Ústí nad Labem, Ústí nad Labem, Czech Republic. ISSN 1213-2489.

[3] KARDAS, E. (2013). The analysis of quality of ferrous burden materials and its effect on the parameters of blast furnace process. In: Metallurgy, Vol. 52, No. 2, pp. 149-152.

[4] MEŠKO, J., ZRAK, A., MULCYZK, K., TOFIL, S. (2014). Microstructure analysis of welded joints after laser welding. In: Manufacturing technology, Vol. 14, No. 3, pp. 355-359. J. E. Purkyne University in Ústí nad Labem, Ústí nad Labem, Czech Republic. ISSN 1213-2489.

[5] MORAVEC, J., BRADAC, J., NOVAKOVA, I. (2014). Ways of numerical prediction of austenitic grain size in heat-affected zone of welds. In: 7th International Conference on Innovative Technologies for Joining Advanced Materials, TIMA 2014, Trans Tech Publications Ltd.

[6] MEŠKO, J., ZRAK, A., MULCYZK, K., TOFIL, S. (2014). Microstructure analysis of welded joints after laser welding. In: Manufacturing technology, Vol. 14, No. 3, pp. 355-359. J. E. Purkyne University in Ústí nad Labem, Ústí nad Labem, Czech Republic. ISSN 1213-2489.

[7] RADEK, N., MEŠKO, J., ZRAK, A. (2014). Technology og laser forming. In: Manufacturing technology. Vol. 14, No. 3, pp. 428-431. J. E. Purkyne University in Ústí nad Labem, Ústí nad Labem, Czech Republic. ISSN 1213-2489.

[8] SINICINA, N., MARTINOVS, A. (2016). Changes in air ions concentration depending on indoor plants activity. In: Agronomy Research, Vol. 14, No. 1, pp. 236-243. Estonian University of Life Sciences, Tartu, Estonia. ISSN 1406-894X.

[9] ORAVCOVÁ, M., PALČEK, P., KRÓL, M. (2016). Dilatometric Measurements of Austenitic Stainless Steel as a Function of Temperature. In: Manufacturing Technology, Vol. 16, No. 3, pp. 230-234. J. E. Purkyne University in Ústí nad Labem, Ústí nad Labem, Czech Republic. ISSN 1213-2489.

[10] PATEK, M., MIČIAN, M., SLÁDEK, A., KADÁŠ, D. (2016). Numerical Analysis of T-Joint Welding with Different Welding Sequences. In: Manufacturing Technology, Vol. 16, No. 3, pp. 234-238. J. E. Purkyne University in Ústí nad Labem, Ústí nad Labem, Czech Republic. ISSN 1213-2489. 
[11] ZRAK, A. MEŠKO, J., MORAVEC, J., NIGROVIČ, R., KADÁŠ, D. (2016). Contactless Thermal Bending of Steel Sheets. In: Manufacturing Technology, Vol. 16, No. 3, pp. 309-313. J. E. Purkyne University in Ústí nad Labem, Ústí nad Labem, Czech Republic. ISSN 1213-2489.

[12] DADO, M., SCHWARZ, M., OČKAJOVÁ, A., HNILICA, R., BOROŠOVÁ, D. (2016). Efficiency of local exhaust ventilation system during stainless steel grinding. In: Manufacturing Technology, Vol. 16, No. 1, pp. 4953. J. E. Purkyne University in Ustí nad Labem, Ústí nad Labem, Czech Republic. ISSN 1213-2489.

[13] MRAČKOVÁ, E., KRIŠTÁK, L., KUČERKA, M., GAFF, M., GAJTANSKA, M. (2016). Creation of wood dust during wood processing: Size analysis, dust separation, and occupational health. In: BioResources. Vol. 11, No. 1, pp. 209-222. ISSN 1930-2126.

[14] ŽÁČOK, L (2010). Research Examination of the Options to Increase the Education Effectiveness in the Technical Subjects at the 7th Grade of Elementary School Using Hypertext Educational Material. In: Informatics in Education. Vol. 9, No. 2, pp. 283-299. Vilnius University Institute of Mathematics and Informatics, Villnius, Lithuania. ISSN 1648-5831.

[15] GIRMAN, V. (2012) Kovové materiály automobilových konštrukcií - II Karoséria a karosárenské plechy. In: Materials engineer. ISSN 1337-8953. Online: <http://www.materialing.com /materialy_auto_konstrukcii> [cit. 2016-06-30].

[16] NOVOTNÝ, J., HONZÍKOVÁ, J., PILOUS, V., STRÁNSKÝ, K. (2015). Properties of welded joints in Power Plant. In: Manufacturing Technology, Vol. 15, No. 6. J. E. Purkyne University in Ústí nad Labem, Ústí nad Labem, Czech Republic. ISSN 1213-2489. 